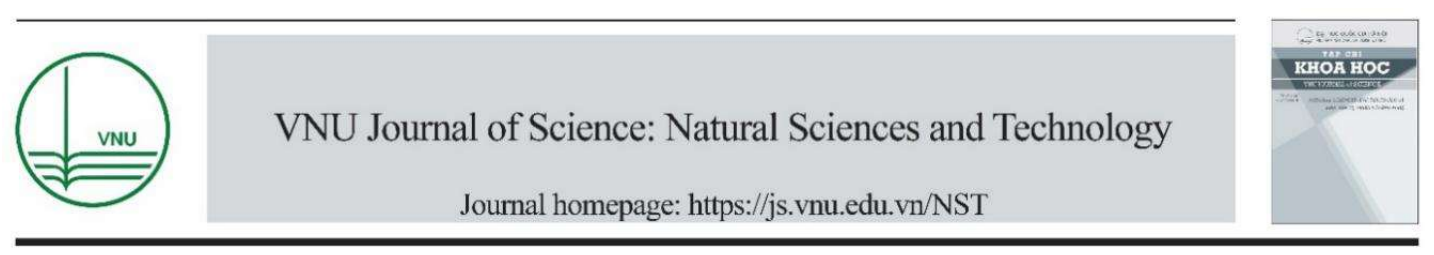

Original Article

\title{
Metal Complexes of $\pi$-expanded Ligand (5): Synthesis, Structural, and Photophysical Characterizations of Green-Red Luminescent Pyrene-based Salicylaldiminato-type Zinc Complexes
}

\author{
Luong Xuan Dien ${ }^{1,2, *}$, Nguyen Thi Thuy Nga ${ }^{1}$ \\ ${ }^{1}$ Hanoi University of Science and Technology, No.1 Dai Co Viet, Hanoi, Vietnam. \\ ${ }^{2}$ Tokyo Metropolitan University, 1-1 Minami-Ohsawa, Hachi-Oji, Tokyo 192-0397, Japan
}

Received xx December 2020

Revised 15 January 2021; Accepted 15 April 2021

\begin{abstract}
A series of pyrene-based salicylaldimine-type ligands containing n-octyl or cyclohexyl or phenyl groups at imine nitrogen group, 1-hydroxy-2-[(N-substituted-imino)methyl]-pyrenes (octyl 1 , cyclohexyl $1 \mathrm{~b}$ and phenyl $1 \mathrm{c}$ ), were synthesized and characterized. The ligands reacting with zinc acetate in the presence of sodium acetate gave the bis(salicylaldiminato)-type $\mathrm{Zn}$ (II) complexes, [bis[2-[(N-substituted-imino)methyl]-1-pyrenolato-N,O] zinc(II)] (octyl 1(Zn), cyclohexyl 1b(Zn), phenyl $1 \mathrm{c}(\mathrm{Zn})$ ). The new ligands and complexes were characterized by ${ }^{1} \mathrm{H}$ NMR, IR spectroscopy, mass spectroscopy, elemental analysis, UV-vis spectroscopy, fluorescence spectroscopy, and X-ray diffraction. The influence of the $\pi$-extended conjugation of the pyrene-based salicylaldiminato-type ligands coordinated to $\mathrm{Zn}^{2+}$ greatly induces red-shift of the complexes $1(\mathrm{Zn}), 1 \mathrm{~b}(\mathrm{Zn})$ and $1 \mathrm{c}(\mathrm{Zn})$ in absorption and emission spectra. These results were confirmed by density-functional theory (DFT) and time-dependent DFT (TDDFT) molecular orbital calculations. Moreover, single crystal structure of simple salicylaldiminato $\mathrm{Zn}(\mathrm{II})$ complex 1 'b( $\mathrm{Zn})$ was compared to that of the corresponding pyrene-type salicylaldiminato complex $1 \mathrm{~b}(\mathrm{Zn})$.
\end{abstract}

Keywords: Coordination chemistry, Zinc complex, Pyrene, $\pi$-Expanded ligand, Salicylaldimine.

\section{Introduction}

In recent years, zinc complexes containing chelating N,O-, N,N-chromophores have become the focus of intense research [1-20]. These complexes contain chromophores that emit visible light at wavelengths depending on the composition and structure of the material, thereby the colour of emission. In addition, some of these compounds exhibit electron-transport properties and, consequently, can be employed in making photoluminescent (PL) and electroluminescent (EL) devices, including organic light-emitting diodes (OLEDs) and sensors $[1,5,8-10,18,20]$. Thus, these properties make them appealing for display screen

\footnotetext{
${ }^{\star}$ Corresponding author.

Email address: dien.luongxuan@hust.edu.vn
}

https://doi.org/10.25073/2588-1140/vnunst.5153 
applications [19]. These same properties make these materials attractive for use as biological imaging agents and sensors [11-17]. Although many zinc complexes have now been designed and synthesized with emission spectra that cover the complete visible spectrum, producing species that emit efficiently and stability at the extremes of this spectral range remains a challenge.<smiles>[R]n1ccc2ccccc2o[Z11]1([R])Oc1ccccc1C</smiles>

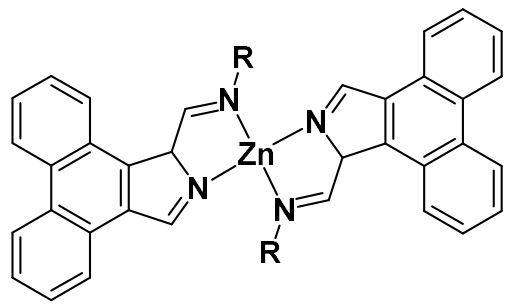<smiles></smiles><smiles></smiles>

Chart 1. Some metal complexes discussed in this paper.

Therefore, to obtain elaborate physical properties and stability on metal complexes, chemical modification of the ligand is one of the most promising strategies. In this method, the replacement of $\pi$-system of the benzene ring to $\pi$-expanded aromatic rings induces drastic change in the properties of the resultant complexes [21].

Salicylaldimine is one type of the Schiff base ligands containing an NO chelate binding for complexation with most of the transition metals such as $\mathrm{Pt}^{2+}, \mathrm{Pd}^{2+}, \mathrm{Ni}^{2+}, \mathrm{Zn}^{2+}$, etc. So far, many salicylaldiminato-type ligands and their complexes have been stated. More recently, these ligands have been speeding up in the syntheses of metal complexes used as catalysts, OLEDs as well as sensors $[1,10,18]$.

We have been interested in the chemistry of salicylaldiminato complexes and expansion of $\pi$ system, and recently our group and other authors have reported the synthesis and characterization of several square planar or tetrahedral complexes containing salicylaldimine derivatives and expansion of $\pi$-system in metal complexes with metals such as $\mathrm{Pt}(\mathrm{II}), \mathrm{Zn}$ (II) (Chart 1) [5,21]. Here, we report the molecular design of new ligands 1, 1a, 1b, the synthesis and basic properties of the corresponding $\mathrm{Zn}(\mathrm{II})$ complexes $1(\mathrm{Zn}), 1 \mathrm{~b}(\mathrm{Zn})$ and $1 \mathrm{c}(\mathrm{Zn})$, and the single crystal diffraction study of $1 b(Z n)$. 


\section{Experimental section}

General Procedures.

General experimental details are already reported in elsewhere [21, 28-30].

General Synthesis. In order to get zinc complexes, we considered the poor solubility of the complexes in ethanol. Therefore, a ligand dissolved in a hot mixed solvent of toluene and ethanol in the presence of sodium acetate for deprotonation. After cooling to room temperature, zinc acetate was added immediately into the mixture. Next, an amount of ethanol was also added into the mixture to precipitate the desired product. After stirring the reaction mixture for $1 \mathrm{~h}$ in room temperature, the product was obtained by filtering and washing with methanol.

Synthesis.

1-Hydroxy-2-[(octylimino)methyl]-pyrene, 1. This ligand has already been reported by our goup in the literature. A mixture of $5(114.1 \mathrm{mg}$, $0.46 \mathrm{mmol})$ [21], $n$-octylamine $(72.9 \mathrm{mg}, 0.56$ mmol, 1.2 eq., Tokyo Chemical Industry Co., Ltd.), and $10 \mathrm{~mL}$ of $\mathrm{CH}_{2} \mathrm{Cl}_{2}$ was stirred at room temperature under ambient condition for $1 \mathrm{~h}$. TLC analysis indicated the complete disappearance of $5\left(R_{f}=0.63\right.$, hexane $/ \mathrm{CHCl}_{3}=$ $1 / 3$ ) and the formation of a new product having a $R_{f}=0.32$ (hexane $/ \mathrm{CHCl}_{3}=1 / 3$ ). The solvent was removed under reduced pressure to give the crude product, $166.4 \mathrm{mg}$ (quant.). Analytical sample was obtained by recrystallization from hexane to give the red powder, $134.8 \mathrm{mg}(82 \%)$; m.p. $98.5{ }^{\circ} \mathrm{C}$; ${ }^{1} \mathrm{H}$ NMR $\left(500 \mathrm{MHz}, \mathrm{CDCl}_{3}\right.$, TMS): $\delta=14.92$ (s, $1 \mathrm{H}), 8.68(\mathrm{~s}, 1 \mathrm{H}), 8.53(\mathrm{~d}, J$ $=8.8 \mathrm{~Hz}, 1 \mathrm{H}), 8.06 \sim 7.90(\mathrm{~m}, 3 \mathrm{H}), 8.01(\mathrm{~d}, J=$ $8.8 \mathrm{~Hz}, 1 \mathrm{H}), 7.85(\mathrm{~d}, J=9.1 \mathrm{~Hz}, 1 \mathrm{H}), 7.77$ (d, $J$ $=9.1 \mathrm{~Hz}, 1 \mathrm{H}), 3.73(\mathrm{t}, J=6.9 \mathrm{~Hz}, 2 \mathrm{H}), 1.80$ (quintet, $J=6.9 \mathrm{~Hz}, 2 \mathrm{H}$ ), 1.46 (quintet, $J=6.9$ $\mathrm{Hz}, 2 \mathrm{H}), 1.40-1.25(\mathrm{~m}, 8 \mathrm{H})$, and $0.89(\mathrm{t}, J=6.9$ $\mathrm{Hz}, 3 \mathrm{H}) \mathrm{ppm}$; IR (KBr): $v=3036(\mathrm{w}), 2954(\mathrm{~s})$, 2929(s), 2856(s), 2800-2200(w, broad, $v_{\mathrm{OH}}$ ), $1623\left(\mathrm{~s}, \quad v_{\mathrm{C}=\mathrm{N}}\right), \quad 1469(\mathrm{~s}), \quad 1380(\mathrm{~s}), \quad 1183(\mathrm{~s})$, 1015(s), 880(s), 842(s), 757(m), 742(m), and $685(\mathrm{~s}) \mathrm{cm}^{-1} ; \lambda_{\max }\left(\mathrm{CH}_{2} \mathrm{Cl}_{2}, 1.64 \times 10^{-7} \mathrm{M}\right) / \mathrm{nm} 526$ $\left(\varepsilon / \mathrm{dm}^{3} \mathrm{~mol}^{-1} \mathrm{~cm}^{-1} 700\right), 430(3,900), 408(3,200)$, $387(3,400), 357$ (21,700), 342 (15,200), 324 (shoulder, 7,400), and 274 (59,700); MS (MALDI): $m / z$ (\%): $358(100)\left[M^{+}+1\right]$; elemental analysis calcd (\%) for $\mathrm{C}_{25} \mathrm{H}_{27} \mathrm{NO}: \mathrm{C}, 83.99 ; \mathrm{H}$, 7.61; N, 3.92; found: C, 83.70; H, 7.60; N, 3.81.

Zinc(II) bis[2-[(octylimino)methyl]-1pyrenolanato-N,O], Zinc complex, $1(\mathrm{Zn})$. A mixture of $1(\mathrm{R}=$ octyl $)(20.0 \mathrm{mg}, 56 \mu \mathrm{mol}, 2$ eq. $)$, sodium acetate anhydrous $(18.3 \mathrm{mg}, 223 \mu \mathrm{mol}, 8$ eq., Junsei Chemical Co.,Ltd.), zinc acetate dihydrate ( $9.5 \mathrm{mg}, 43 \mu \mathrm{mol}, 1.5$ eq.), and $6 \mathrm{~mL}$ of a solvent mixture of toluene $(1 \mathrm{~mL})$ and ethanol $(5$ $\mathrm{mL}$ ) was stirred at room temperature. After being stirred for $1 \mathrm{~h}$, the precipitated solid was collected and washed with $\mathrm{MeOH}$ to give the orange powder, $18.9 \mathrm{mg}(87 \%)$. M.p. $195{ }^{\circ} \mathrm{C}$; IR (KBr): $v=$ 3035(w), 2924(s), 2854(s), 1615(s, $\left.v_{\mathrm{C}=\mathrm{N}}\right), 1571(\mathrm{~s})$, 1473(s), 1456(m), 1428(w), 1418(m), 1402(s), 1393(s), 1367(w), 1312(w), 1277(m), 1260(m), 1186(s), 1140(w), 1127(w), 986(w), 842(s), 831(w), 759(s), 686(m), 553(m), 500(w), 483(w), and $466(\mathrm{w}) \mathrm{cm}^{-1} ; \lambda_{\max }\left(\mathrm{CH}_{2} \mathrm{Cl}_{2}, 1.66 \times 10^{-5} \mathrm{M}\right) / \mathrm{nm}$ $485\left(\varepsilon / \mathrm{dm}^{3} \mathrm{~mol}^{-1} \mathrm{~cm}^{-1} 10,179\right), 464(9,720), 435$ (shoulder, 6,690), $381(42,625), 361(28,890)$ and 342 (sh., 12,900); MS (APCI): $m / z$ (\%): 777.33 (100) $\left([\mathrm{M}+\mathrm{H}]^{+}\right)$; elemental analysis calcd $(\%)$ for $\mathrm{C}_{50} \mathrm{H}_{52} \mathrm{~N}_{2} \mathrm{O}_{2} \mathrm{Zn}$ : C, 77.16; H, 6.73; N, 3.60; found: C, 76.95; H, 6.78; N, 3.56.

1-Hydroxy-2-[(cyclohexylimino)methyl]pyrene, $1 \mathrm{~b}$. A mixture of $5(130.0 \mathrm{mg}, 0.53 \mathrm{mmol})$, cyclohexylamine $(64 \mathrm{mg}, 0.65 \mathrm{mmol}, 1.2$ eq., Kanto Chemical Co., Inc.), 2 drops of glacial acetic acid and $5 \mathrm{~mL}$ of $\mathrm{CH}_{2} \mathrm{Cl}_{2}$ was stirred at room temperature under ambient condition for $1 \mathrm{~h}$. TLC analysis indicated the complete disappearance of 5 $\left(R_{f}=0.63\right.$, hexane $\left./ \mathrm{CHCl}_{3}=1 / 3\right)$ and the formation of a new product having a $R_{f}=0.75$ $\left(\mathrm{CHCl}_{3} / \mathrm{CH}_{3} \mathrm{OH}=50 / 1\right)$. The solvent was removed under reduced pressure to give the crude product, $159.0 \mathrm{mg}(92 \%)$. Analytical sample was obtained by recrystallization from a solvent mixture of hexane and chloroform to give the red powder, $125.0 \mathrm{mg}$ (72 \%); M.p.: $186{ }^{\circ} \mathrm{C} ;{ }^{1} \mathrm{H}$ NMR (500 $\left.\mathrm{MHz}, \mathrm{CDCl}_{3}, \mathrm{TMS}\right): \delta=15.10$ (s, $\left.1 \mathrm{H}\right), 8.72$ (s, $1 \mathrm{H}), 8.53(\mathrm{~d}, \mathrm{~J}=9.3 \mathrm{~Hz}, 1 \mathrm{H}), 8.05(\mathrm{~d}, \mathrm{~J}=7.5 \mathrm{~Hz}$, 1H), 8.03-7.97 (m, 2H), $7.95(\mathrm{~s}, 1 \mathrm{H}), 7.93(\mathrm{t}, \mathrm{J}=7.8$ $\mathrm{Hz}, 1 \mathrm{H}), 7.85(\mathrm{~d}, \mathrm{~J}=9.0 \mathrm{~Hz}, 1 \mathrm{H}), 7.77(\mathrm{~d}, \mathrm{~J}=9.0$ 
$\mathrm{Hz}, 1 \mathrm{H}), 3.45(\mathrm{~m}, 1 \mathrm{H}), 1.96(\mathrm{~m}, 2 \mathrm{H}), 1.90(\mathrm{~m}$, $2 \mathrm{H}), 1.72-1.64(\mathrm{~m}, 3 \mathrm{H}), 1.49-1.30(\mathrm{~m}, 3 \mathrm{H})$; IR $(\mathrm{KBr}): v=3040(\mathrm{~m}), 2931(\mathrm{~s}), 2856(\mathrm{~s}), 2800-$ $2200\left(\mathrm{w}\right.$, broad, $\left.v_{\mathrm{OH}}\right), 1627\left(\mathrm{~s}, v_{\mathrm{C}=\mathrm{N}}\right), 1603(\mathrm{~m})$, 1587(s), 1563(m), 1481(m), 1465(m), 1449(m), 1381(s), 1298(s), 1248(m), 1236(m), 1220(m), 1183(s), 1141(m), 1085(s), 1012(s), 978(m), 968(m), 891(s), 883(m), 842(s), 831(m), 803(m), 763(m), 752(m), 741(s), and 688(s) $\mathrm{cm}^{-1} ; \lambda_{\max }$ $\left(\mathrm{CH}_{2} \mathrm{Cl}_{2}, 2.14 \times 10^{-5} \mathrm{M}\right) / \mathrm{nm} 528\left(\varepsilon / \mathrm{dm}^{3} \mathrm{~mol}^{-1} \mathrm{~cm}^{-}\right.$ $\left.{ }^{1} 1,000\right), 430(4,200), 406(3,400), 387(3,700)$, 357 (21,400), $341(15,200), 327$ (shoulder, 8,300); MS (APCI): Calcd. for $\mathrm{C}_{23} \mathrm{H}_{21} \mathrm{NO}$ $\left([\mathrm{M}+\mathrm{H}]^{+}\right)$: 328; Found: 328; elemental analysis calcd (\%) for $\mathrm{C}_{23} \mathrm{H}_{21} \mathrm{NO}$ : C, 84.37; $\mathrm{H}, 6.46 ; \mathrm{N}$, 4.28. Found: C, 84.09; H, 6.47; N, 4.25.

Bis[2-[(cyclohexylimino)methyl]-1pyrenolanato-N,O] Zinc(II), $1 \mathrm{~b}(\mathrm{Zn})$. A mixture of $1 \mathrm{~b}(30.0 \mathrm{mg}, 92 \mu \mathrm{mol}, 2 \mathrm{eq}$.), sodium acetate anhydrous (28.3 mg, $345 \mu \mathrm{mol}, 7.5$ eq., Junsei Chemical Co.,Ltd.), zinc acetate dihydrate (15.2 $\mathrm{mg}, 69 \mu \mathrm{mol}, 1.5$ eq.), and $6 \mathrm{~mL}$ of a solvent mixture of toluene $(1 \mathrm{~mL})$ and ethanol $(5 \mathrm{~mL})$ was stirred at room temperature. After being stirred for $1 \mathrm{~h}$, the precipitated solid was collected and washed with $\mathrm{MeOH}$ to give the orange powder, $26.7 \mathrm{mg}(69 \%)$. M.p. $>300^{\circ} \mathrm{C}$; ${ }^{1} \mathrm{H}$ NMR $\left(500 \mathrm{MHz}, \mathrm{CDCl}_{3}, \mathrm{TMS}\right): \delta=8.75(\mathrm{~d}$, $J=9.1 \mathrm{~Hz}, 2 \mathrm{H}), 8.70(\mathrm{~s}, 2 \mathrm{H}), 7.96(\mathrm{dd}, J=6.3$ and $2.4 \mathrm{~Hz}, 2 \mathrm{H}), 7.89(\mathrm{~d}, J=9.2 \mathrm{~Hz}, 2 \mathrm{H})$, $7.87 \sim 7.84(\mathrm{~m}, 6 \mathrm{H}), 7.75(\mathrm{~d}, J=9.0 \mathrm{~Hz}, 2 \mathrm{H}), 7.61$ $(\mathrm{d}, J=9.0 \mathrm{~Hz}, 2 \mathrm{H}), 3.36(\mathrm{~m}, 2 \mathrm{H}), 2.00-1.80(\mathrm{~m}$, $6 \mathrm{H}), 1.70-1.45(\mathrm{~m}, 4 \mathrm{H}), 1.35-1.10(\mathrm{~m}, 8 \mathrm{H})$, and $0.41(\mathrm{~m}, 2 \mathrm{H}) \mathrm{ppm}$; IR $(\mathrm{KBr}): v=3033(\mathrm{~m})$, 2929(s), 2856(s), 1609(s, $\left.\quad v_{\mathrm{C}=\mathrm{N}}\right), \quad 1571(\mathrm{~s})$, 1489(m), 1472(s), 1450(m), 1428(m), $1419(\mathrm{~m})$, 1406(s), 1394(s), 1367(m), 1347(w), 1329(m), 1313(m), 1277(m), 1259(m), 1223(m), 1190(s), 1182(m), 1152(w), 1141(s), 1127(m), 1112(w), 1077(s), 1071(s), 1017(s), 985(m), 968(w), 893(m), 875(m), 840(s), 829(m), 817(w), 806(m), 793(w), 759(s), 752(s), 684(m), 605(w), 553(m), 499(m) and $466(\mathrm{w}) \mathrm{cm}^{-1} ; \lambda_{\max }\left(\mathrm{CH}_{2} \mathrm{Cl}_{2}\right.$, $\left.1.78 \times 10^{-5} \mathrm{M}\right) / \mathrm{nm} 485\left(\varepsilon / \mathrm{dm}^{3} \mathrm{~mol}^{-1} \mathrm{~cm}^{-1} 13,100\right)$, $461 \quad(12,400), 432$ (shoulder, 7,800), 382 $(52,300), 364$ (31,400), 344 (sh., 12,600), and $310(70,400)$ (the measurement in different concentration, $1.78 \times 10^{-4} \mathrm{M}$, in $\mathrm{CH}_{2} \mathrm{Cl}_{2}$ showed the similar spectrum), MS (APCI): $m / z(\%)$ : $717.28(100)\left([\mathrm{M}+\mathrm{H}]^{+}\right)$; elemental analysis calcd (\%) for $\mathrm{C}_{46} \mathrm{H}_{40} \mathrm{~N}_{2} \mathrm{O}_{2} \mathrm{Zn}: \mathrm{C}, 76.93 ; \mathrm{H}, 5.61 ; \mathrm{N}$, 3.90; found: $\mathrm{C}, 77.01 ; \mathrm{H}, 5.61 ; \mathrm{N}, 3.83$. Absorption spectra measured at $1.78 \times 10^{-4} \mathrm{M}$ in $\mathrm{CH}_{2} \mathrm{Cl}_{2}$ afforded the mostly identical result; therefore, no concentration dependencies were observed in this concentration region. Additionally, quantitative absorption spectra measured in toluene and acetonitrile also showed the different spectra shapes. A single crystal suitable for diffraction study was obtained by slow diffusion of a system of dichloromethane and hexane at room temperature to give blockshaped crystals.

1-Hydroxy-2-[(phenylimino)methyl]pyrene, $1 \mathrm{c}$. A mixture of $5(50.0 \mathrm{mg}, 0.20 \mathrm{mmol}$, 1 eq.), aniline ( $56 \mu \mathrm{L}, 0.61 \mathrm{mmol}, 3$ eq., Kanto Chemical Co., Inc.), glacial acetic acid $(20 \mu \mathrm{L}$, $0.34 \mathrm{mmol}, 1.7$ eq.) and $2 \mathrm{~mL}$ of toluene was stirred at $100{ }^{\circ} \mathrm{C}$ under ambient condition for 24h. TLC analysis indicated the complete disappearance of $5\left(R_{f}=0.63\right.$, hexane $/ \mathrm{CHCl}_{3}=$ $1 / 3$ ) and the formation of a new product having a $R_{f}=0.48$ (hexane/ $\mathrm{CHCl}_{3}=2 / 3$ ). The solvent was removed under reduced pressure to give the crude product. The product $1 \mathrm{c}$ was purified by flash chromatography (hexane/ $\mathrm{CHCl}_{3}=2 / 3$ as eluent) to give the yellow powder, $65.2 \mathrm{mg}$ (99\%); M.p.: $172{ }^{\circ} \mathrm{C} \mathrm{MS}$; IR (KBr): $v=1617$ (s, $v_{\mathrm{C}=\mathrm{N}}$ ), (APCI): $m / z(\%): 321.17$ (100) $\left[M^{+}\right] ; \lambda_{\max }$ $\left(\mathrm{CH}_{2} \mathrm{Cl}_{2}, 5.85 \times 10^{-5} \mathrm{M}\right) / \mathrm{nm} 448\left(\varepsilon / \mathrm{dm}^{3} \mathrm{~mol}^{-1} \mathrm{~cm}^{-}\right.$ 1 4,670), $356(32,140), 335(41,130), 327$ $(41,060)$; elemental analysis calcd $(\%)$ for $\mathrm{C}_{23} \mathrm{H}_{21} \mathrm{NO}: \mathrm{C}, 85.96 ; \mathrm{H}, 4.70$; N, 4.36. Found: $\mathrm{C}$, 85.66; H, 4.62; N, 4.41.

Bis[2-[(phenylimino)methyl]-1pyrenolanato-N,O] Zinc(II), 1c(Zn). A mixture of $1 \mathrm{c}(20.5 \mathrm{mg}, 64 \mu \mathrm{mol}, 2 \mathrm{eq}$.), sodium acetate anhydrous $(20.3 \mathrm{mg}, 247 \mu \mathrm{mol}, 7.5$ eq., Junsei Chemical Co.,Ltd.), zinc acetate dihydrate (10.5 $\mathrm{mg}, 48 \mu \mathrm{mol}, 1.5$ eq.), and $6 \mathrm{~mL}$ of a solvent mixture of toluene $(1 \mathrm{~mL})$ and ethanol $(5 \mathrm{~mL})$ was stirred at room temperature. After being stirred for $1 \mathrm{~h}$, the precipitated solid was 
collected and washed with $\mathrm{MeOH}$ to give the yellow powder, $17.3 \mathrm{mg}(77 \%)$. M.p. $>300{ }^{\circ} \mathrm{C}$; IR $(\mathrm{KBr}): v=1603\left(\mathrm{~s}, v_{\mathrm{C}=\mathrm{N}}\right) ; \lambda_{\max }\left(\mathrm{CH}_{2} \mathrm{Cl}_{2}, 1.77\right.$ $\left.\times 10^{-5} \mathrm{M}\right) / \mathrm{nm} 508\left(\varepsilon / \mathrm{dm}^{3} \mathrm{~mol}^{-1} \mathrm{~cm}^{-1} 11,820\right), 380$ (43,650), 355 (sh, 65,480), 339 (79,330); MS (APCI): $m / z \quad(\%): 705.16 \quad(100) \quad\left([\mathrm{M}+\mathrm{H}]^{+}\right)$; elemental analysis calcd (\%) for $\mathrm{C}_{46} \mathrm{H}_{28} \mathrm{~N}_{2} \mathrm{O}_{2} \mathrm{Zn}$ : C, 78.25; H, 4.00; N, 3.97; found: C, 78.32; H, $4.09 ; \mathrm{N}, 3.93$.

\section{Results and Discussion}

Synthesis, Mass and IR Spectra.

The pyrene-based salicylaldiminato-type ligands 1, 1b, 1c (Scheme 1) were prepared and characterized similar to the method described in previous publications [21, 28-30]. The imine formation reaction of aniline or cyclohexylamine or $n$-octylamine on 2-formyl-1-hydroxypyrene 5 in the presence of acetic acid as catalyst afforded $1,1 \mathrm{~b}$ and $1 \mathrm{c}$, respectively, quantitatively as highly soluble red or yellow solids. As mentioned in the previous publication [21], the compound 5 is was prepared from commercially available pyrene in five Generally, the synthesis of zinc(II) complexes takes long reaction time or uses special zinc(II) salts or strong bases such as $\mathrm{NaH}$. In this study, we used an effective method that consider solubility of formed product, a used solvent mixture of toluene and ethanol, and suitable base such as sodium acetate or sodium propionate even in few minutes at room temperature. These highly soluble complexes were obtained from the reaction mixture as the orange or red solids in high yields (70-90\%). It should be mentioned that the new complexes $1(\mathrm{Zn}), 1 \mathrm{~b}(\mathrm{Zn})$ and $1 \mathrm{c}(\mathrm{Zn})$ are stable and have high melting point under ambient condition but they may be decomposed easily when they contact with an acid or being kept for a long time in solution. This phenomenon is also found similar to the simple salicylaldiminato zinc(II) complexes $[8,9,22,23]$.

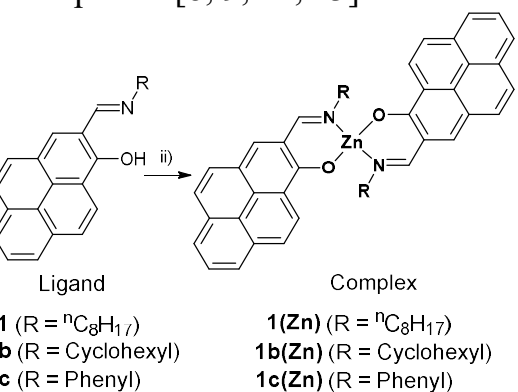

Scheme 1. Reagents and conditions: a) $\mathrm{RNH}_{2} / \mathrm{AcOH} / \mathrm{CH}_{2} \mathrm{Cl}_{2}$ / RT, b) $\mathrm{Zn}(\mathrm{OAc})_{2} / \mathrm{NaOAc} / \mathrm{PhMe}$ and $\mathrm{EtOH} / \mathrm{RT}$.

All obtained complexes were subjected to analysis by mass spectrometry (MS). The measured data are suitable to the theoretical data for all zinc(II) complexes (see details in experimental section). Spectroscopic behaviors are also informative to determine the structure of zinc complexes. Along with the reasonable elemental analyses and mass spectroscopy of the ligands and the corresponding zinc complexes, the characteristic behaviors were observed in IR spectra (Figure 1), i.e., the lower-frequency shift of the imine $\mathrm{C}=\mathrm{N}$ stretching mode $\left(v_{\mathrm{CN}}\right)$ attributable to the complex formation [21]. The intense $v_{\mathrm{CN}}$ signals of the ligands $1,1 \mathrm{~b}, 1 \mathrm{c}, 1623$, $1627,1617 \mathrm{~cm}^{-1}$, were shifted to lower frequency regions in the zinc complexes $1(\mathrm{Zn}), 1 \mathrm{~b}(\mathrm{Zn})$, $1 \mathrm{c}(\mathrm{Zn}), 1615,1609,1603 \mathrm{~cm}^{-1}$, respectively. Thus, the effect of the substituents on imine group induces the change for the $\mathrm{C}=\mathrm{N}$ stretching frequency in zinc complexes and $\pi$-expansion only influences the $v_{\mathrm{CN}}$ of the ligand as the lower frequency shift.

\section{Diffraction Study.}

Crystallization was attempted for $1(\mathrm{Zn})$, $1 \mathrm{~b}(\mathrm{Zn}), 1 \mathrm{c}(\mathrm{Zn})$, and fortuitously, single crystals 
suitable for X-ray diffraction analysis were obtained by slow diffusion of hexane into a solution of $1 \mathrm{~b}(\mathrm{Zn})$ in dichloromethane. The structures of the mononuclear complexes $1 \mathrm{~b}(\mathrm{Zn})$ and the complex 1 'b( $\mathrm{Zn})[24]$ were shown in Figure 2 and Figure 3, respectively, and X-ray experimental parameters were listed in Table 1. In contrast to the structure of the reported $\mathrm{Pt}(\mathrm{II})$ complex [21], the nearly planar structure, $\mathrm{Zn}$ (II)

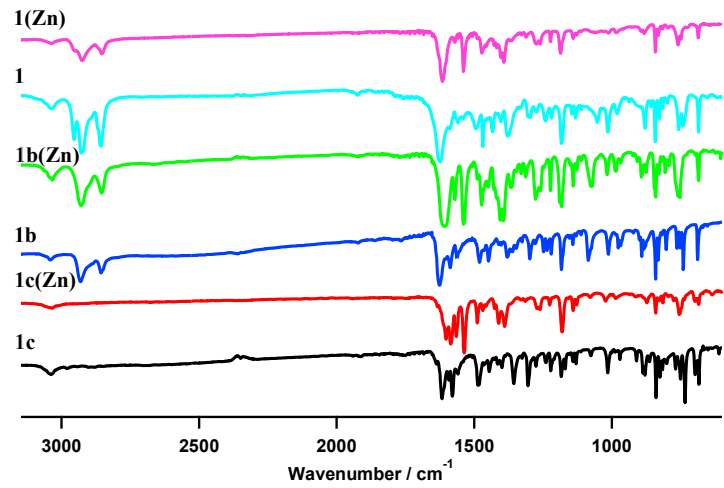

Figure 1. IR spectra of the ligands $1,1 \mathrm{~b}, 1 \mathrm{c}$ and the corresponding zinc(II) complexes $1(\mathrm{Zn}), 1 \mathrm{~b}(\mathrm{Zn})$,

$$
1 \mathrm{c}(\mathrm{Zn}) \text {. }
$$

complex $1 b(Z n)$ takes the tetrahedral structure. It is the most stable structure for this type of zinc complexes because of the prevention of coordinating groups that coordinate to zinc center to form five-coordinate or six-coordinate zinc complexes that we can usually find in salicylaldiminato zinc(II) complexes. This structure of $1 b(\mathrm{Zn})$ is different from that of the simple salicylaldiminato zinc complex $1^{\prime} b(\mathrm{Zn})$, the square-planar structure. The planes in $1 b(Z n)$ defined by the three atoms Zn1-N1-O1 and Zn1$\mathrm{N} 1{ }^{*}-\mathrm{O} 1^{*}$ are less deviated from perpendicular (the dihedral angle $=86.4^{\circ}$ ) than those reported in the literature $\left(81.7^{\circ}[25]\right.$ and $\left.83.2^{\circ}[26]\right)$. The bond lengths of Zn-N (2.018 (5)-2.029(5) $\AA$ ) in $1 \mathrm{~b}(\mathrm{Zn})$ are comparable to those of $\mathrm{Zn}-\mathrm{N}$ $(2.015(2) \AA)$ in 1 'b( $Z n)$. Most interestingly, the bond lengths of $\mathrm{Zn}-\mathrm{O}$ (1.928(5)-1.946(5) $\AA$ ) in $1 \mathrm{~b}(\mathrm{Zn})$ are longer than those of $\mathrm{Zn}-\mathrm{O}$ (1.891(2) $\AA)$ in $1^{\prime} \mathrm{b}(\mathrm{Zn})$. The $\mathrm{L}-\mathrm{Zn}-\mathrm{L}$ angles are in the range of $90.46(19)$ to $96.06(19)^{\circ}$, which illustrates that $1 \mathrm{~b}(\mathrm{Zn})$ and 1 'b( $\mathrm{Zn})$ display distorted tetrahedral and square-planar geometries, respectively.

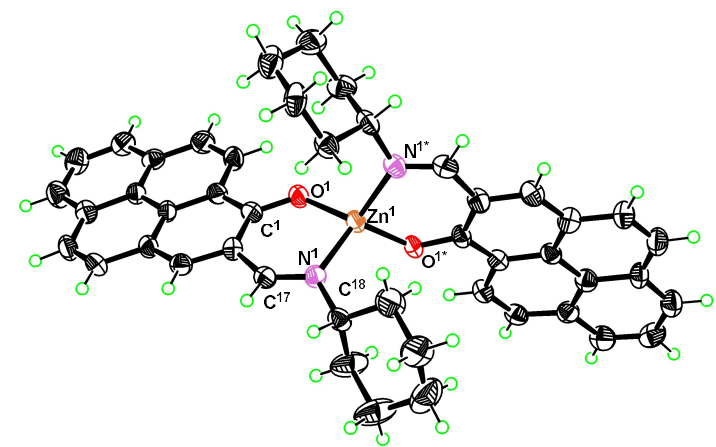

Figure 2. ORTEP drawings of $1 b(\mathrm{Zn})$. Thermal ellipsoids are 50\% probability levels. Hydrogen atoms have been omitted for clarity. (a) Selected distances $\left(d\right.$ in $\AA$ ) and angles $\left(\angle\right.$ in $\left.{ }^{\circ}\right): d\left(\mathrm{Zn}^{1}-\mathrm{N}^{1}\right)$ : 2.018(5), $d\left(\mathrm{Zn}^{1}-\mathrm{N}^{1 *}\right): 2.029(5), d\left(\mathrm{Zn}^{1}-\mathrm{O}^{1}\right): 1.928(5)$, $d\left(\mathrm{Zn}^{1}-\mathrm{O}^{1 *}\right): 1.946(5), d\left(\mathrm{O}^{1}-\mathrm{C}^{1}\right): 1.324(7), d\left(\mathrm{O}^{1 *}-\mathrm{C}^{1^{*}}\right)$ : $1.318(7), d\left(\mathrm{~N}^{1}-\mathrm{C}^{17}\right): 1.295(8), d\left(\mathrm{~N}^{1 *}-\mathrm{C}^{17^{*}}\right): 1.300(8)$, $\angle\left(\mathrm{N}^{1}-\mathrm{Zn}^{1}-\mathrm{O}^{1}\right): \quad 96.06(19), \quad \angle\left(\mathrm{N}^{1^{*}}-\mathrm{Zn}^{1}-\mathrm{O}^{1^{*}}\right)$ : 95.79(19), $\angle\left(\mathrm{N}^{1}-\mathrm{Zn}^{1}-\mathrm{O}^{1^{*}}\right)$ : 114.2(2), $\angle\left(\mathrm{N}^{1^{*}}-\mathrm{Zn}^{1}-\mathrm{O}^{1}\right)$ : 114.66(19), $\angle\left(\mathrm{Zn}^{1}-\mathrm{O}^{1}-\mathrm{C}^{1}\right): 125.6(4), \angle\left(\mathrm{Zn}^{1}-\mathrm{O}^{1 *}-\mathrm{C}^{1^{*}}\right)$ : $125.9(4), \angle\left(\mathrm{C}^{17}-\mathrm{N}^{1}-\mathrm{Zn}^{1}\right): 119.8(4), \angle\left(\mathrm{C}^{17^{*}}-\mathrm{N}^{1 *}-\mathrm{Zn}^{1}\right)$ : 119.7(4).

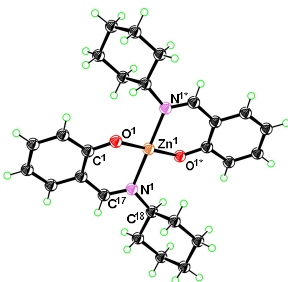

(a)

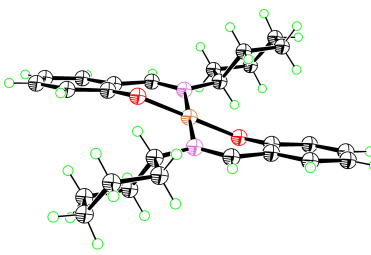

(b)
Figure 3. ORTEP drawings of 1 ' $b(\mathrm{Zn})$. Thermal ellipsoids are $50 \%$ probability levels. Hydrogen atoms have been omitted for clarity. (a) Selected distances $\left(d\right.$ in $\AA$ ) and angles $\left(\angle\right.$ in $\left.{ }^{\circ}\right): d\left(Z^{1}-\mathrm{N}^{1}\right)=$ $d\left(\mathrm{Zn}^{1}-\mathrm{N}^{1 *}\right)=2.015(2), d\left(\mathrm{Zn}^{1}-\mathrm{O}^{1}\right)=d\left(\mathrm{Zn}^{1}-\mathrm{O}^{1 *}\right)=$ $1.891(2), d\left(\mathrm{O}^{1 \mathrm{~A}}-\mathrm{C}^{1}\right)=d\left(\mathrm{O}^{1 *}-\mathrm{C}^{1 *}\right): 1.314(3), d\left(\mathrm{~N}^{1}-\mathrm{C}^{17}\right)$ $=d\left(\mathrm{~N}^{1 *}-\mathrm{C}^{17^{*}}\right)=1.287(3), \angle\left(\mathrm{N}^{1}-\mathrm{Zn}^{1}-\mathrm{O}^{1}\right)=\angle\left(\mathrm{N}^{1 *}-\mathrm{Zn}^{1}-\right.$ $\left.\mathrm{O}^{1^{*}}\right)=90.46(19), \angle\left(\mathrm{N}^{1}-\mathrm{Zn}^{1}-\mathrm{O}^{1 *}\right)=\angle\left(\mathrm{N}^{1^{*}}-\mathrm{Zn}^{1}-\mathrm{O}^{1}\right)=$ 89.54, $\angle\left(\mathrm{Zn}^{1}-\mathrm{O}^{1}-\mathrm{C}^{1}\right)=\angle\left(\mathrm{Zn}^{1}-\mathrm{O}^{1 *}-\mathrm{C}^{\mathrm{C}^{*}}\right)=125.65(15)$, $\angle\left(\mathrm{C}^{17}-\mathrm{N}^{1}-\mathrm{Zn}^{1}\right)=\angle\left(\mathrm{C}^{17^{*}}-\mathrm{N}^{1^{*}}-\mathrm{Zn}^{1}\right)=122.11(15)$. 
Table 1 Crystal data and structure refinement details for $\mathbf{1 b}(\mathbf{Z n})$ and $\mathbf{1}^{\prime} \mathbf{b}(\mathbf{Z n})$

\begin{tabular}{|c|c|c|}
\hline & $1 b(Z n)$ & $1^{\prime \prime b}(\mathrm{Zn})$ \\
\hline Mol. Formula & $\mathrm{C}_{46} \mathrm{H}_{40} \mathrm{ZnN}_{2} \mathrm{O}_{2}$ & $\mathrm{C}_{26} \mathrm{H}_{32} \mathrm{ZnN}_{2} \mathrm{O}_{2}$ \\
\hline Mol. Weight & 718.07 & 469.91 \\
\hline Crystal habit & Orange, block & Yellow, block \\
\hline Crystal dimens./mm & $0.28 \times 0.14 \times 0.05$ & $0.28 \times 0.25 \times 0.21$ \\
\hline Crystal system & Monoclinic & Triclinic \\
\hline Space group & $\mathrm{C} 2 / \mathrm{c}$ & P-1 \\
\hline$a(\AA)$ & $40.84(4)$ & $6.470(2)$ \\
\hline$b(\AA)$ & $9.148(9)$ & $7.814(2)$ \\
\hline$c(\AA)$ & $19.465(19)$ & $12.035(2)$ \\
\hline$\alpha(\operatorname{deg})$ & 90 & $97.70(3)$ \\
\hline$\beta(\operatorname{deg})$ & $96.811(10)$ & $101.90(3)$ \\
\hline$\gamma(\operatorname{deg})$ & 90 & $104.88(3)$ \\
\hline $\mathrm{V}\left(\AA^{3}\right)$ & $7220(12)$ & $564.1(3)$ \\
\hline$Z$ & 8 & 1 \\
\hline$D_{\text {calcd }}\left(\mathrm{g} / \mathrm{cm}^{3}\right)$ & 1.321 & 1.383 \\
\hline$\mu(\operatorname{Mo~K} \alpha)\left(\mathrm{cm}^{-1}\right)$ & 7.220 & 11.000 \\
\hline $\mathrm{T} / \mathrm{K}$ & $173(1)$ & $298(2)$ \\
\hline $2 \theta_{\max }(\mathrm{deg})$ & 54.77 & 55.00 \\
\hline Radiation & $\operatorname{MoK} \alpha$ & $\operatorname{MoK} \alpha$ \\
\hline $\operatorname{MoKa}(1=0.71075 \AA)$ & & \\
\hline $\mathrm{R} 1, w R 2(\mathrm{I}>2 \sigma \mathrm{I})$ & $0.0864 / 0.3380$ & $0.039 / 0.105$ \\
\hline Rint & 0.086 & 0.056 \\
\hline
\end{tabular}

(a)

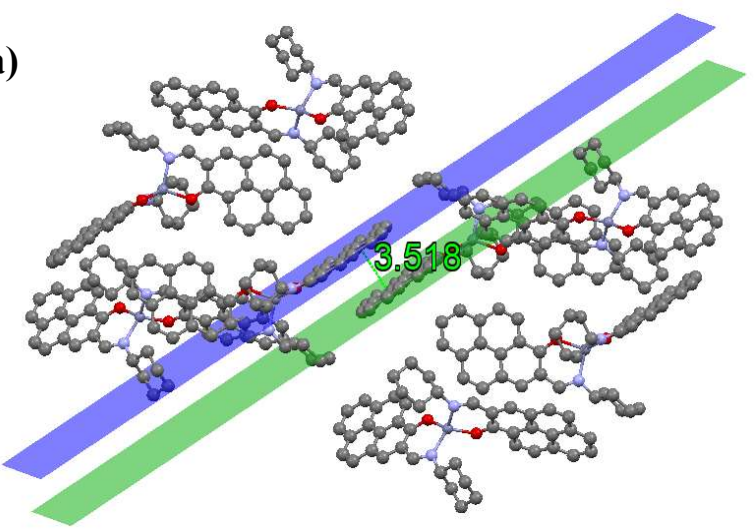

(b)

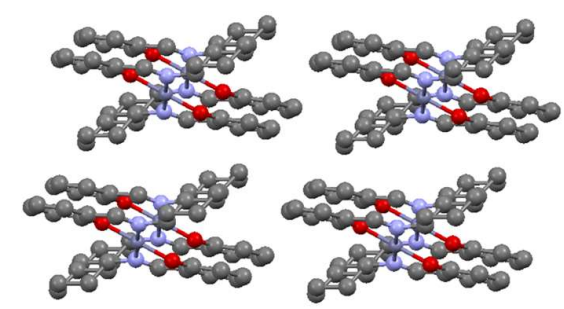

Figure 4: Crystal packing structures of the zinc(II) complexes: (a) $\mathbf{1 b}(\mathbf{Z n})$ and (b) $\mathbf{1}^{\prime} \mathbf{b}(\mathbf{Z n})$

The crystal packing structures of the complexes $1 b(\mathrm{Zn})$ and 1 'b( $\mathrm{Zn})$ were shown in Figure 4. As clear from this figure, both complexes have intermolecular interactions such as $\mathrm{CH}-\pi$ and $\pi-\pi$ interactions that induce low fluorescence quantum yield. Photophysical 
study. The absorption spectra of the ligands 1 , $1 \mathrm{~b}, 1 \mathrm{c}$ and the corresponding zinc(II) complexes $1(\mathrm{Zn}), 1 \mathrm{~b}(\mathrm{Zn})$ and $1 \mathrm{c}(\mathrm{Zn})$ were recorded in dichloromethane and shown in Figure 5 and the emission spectra of the complexes $1(\mathrm{Zn}), 1 \mathrm{~b}(\mathrm{Zn})$ and $1 \mathrm{c}(\mathrm{Zn})$ were shown in Figure 6. Their photophysical properties such as absorption and emission maxima wavelengths ( $\lambda_{\text {abs }}$ and $\lambda_{\mathrm{em}}$, respectively) and molar extinction coefficient $\left(\varepsilon_{\max }\right)$ were listed in Table 2.

The absorption spectra of the compounds of the type c (phenyl group on imine group) are substantially red-shifted (ca. 18 and $23 \mathrm{~nm}$, for the ligand and complex, respectively) with respect to those of the type of alkyl groups on imine group, indicating extension of the delocalized $\pi$-orbitals to the phenyl group in the compound $\mathbf{c}$ [5]. This delocalization occurs to a lesser extent in compounds with alkyl groups because they don't have $\pi$-electrons to conjugate with pyrene moieties. This effect has already been observed in the molecular structures of the simple

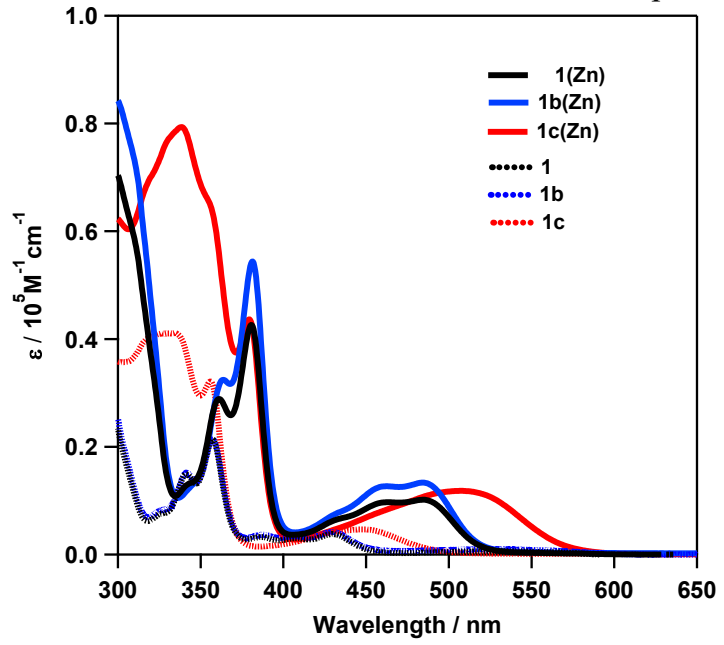

Figure 5. Absorption spectra of the ligands 1, 1b, $1 \mathbf{c}$ (dotted lines) and the corresponding complexes $\mathbf{1}(\mathbf{Z n}), \mathbf{1 b}(\mathbf{Z n}), \mathbf{1 c}(\mathbf{Z n})$ (solid lines) in $\mathrm{CH}_{2} \mathrm{Cl}_{2}$ at 25 ${ }^{\circ} \mathrm{C}$.

Compared to salicyl-aldiminato zinc complexes, the influence of the $\pi$-extended conjugation of the pyrene-based salicyl- salicylaldimine ligands and simple salicylaldiminato zinc(II) complexes [8,22,23].

Another interesting observation is the red-shift of the absorption spectra of the complexes $\mathbf{1}(\mathbf{Z n})$, $\mathbf{1 b}(\mathbf{Z n})$ and $\mathbf{1 c}(\mathbf{Z n}) \quad(55, \quad 55$ and $60 \mathrm{~nm}$, respectively) relative to those of the corresponding ligands (Figure 5). These large shifts suggest an enhancement of the $\pi$-conjugation due to the bidentate complexation of the ligand to the $\mathrm{d}^{10}$ spectroscopically inactive $\mathrm{Zn}^{2+}[5]$.

The fluorescence spectrum of complex $\mathbf{1 c}(\mathbf{Z n})$ shows red-shifts $(76 \mathrm{~nm})$ relative to the complexes $\mathbf{1}(\mathbf{Z n})$ and $\mathbf{1 b}(\mathbf{Z n})$ (Figure 6), similar to those observed in the absorption spectra. This is in accordance with the results obtained by other authors for the spectroscopic properties observed with other zinc complexes and the corresponding ligands [5,8]. According to Figure 6 and Table 2, like the reported salicylaldiminato $\mathrm{Zn}(\mathrm{II})$ complexes, the emission spectra of these zinc complexes show the potentials as the green and red emitters in OLEDs $[1,8,19]$.

aldiminato-type ligands coordinated to $\mathrm{Zn}^{2+}$ greatly induces red-shift of the complexes $1(\mathbf{Z n})$, $\mathbf{1 b}(\mathbf{Z n})$ and $\mathbf{1 c}(\mathbf{Z n})$ in absorption and emission spectra $[8,22,23]$.

\section{Theoretical studies.}

Theoretical studies were carried out for the further understandings of complexes $\mathbf{1}(\mathbf{Z n})$, $\mathbf{1 b}(\mathbf{Z n})$ and $\mathbf{1 c}(\mathbf{Z n})$. The DFT calculations using Gaussian 09 were performed with density functional theory, B3LYP, using the basic set 6$31 \mathrm{G}(\mathrm{d})$ for all atoms. The geometries were fully optimized, and the agreement between the calculated distances and angles for $\mathbf{1 b}(\mathbf{Z n})$ with the corresponding values obtained from single crystal $\mathrm{X}$-ray diffraction studies (see above) is very good. Therefore, it is expected that the structures calculated for $\mathbf{1}(\mathbf{Z n})$ and $\mathbf{1}(\mathbf{Z n})$ will be reliable.

Energy level is an important factor for emitting and charge transport materials used in OLEDs. The injection and transport barrier of charge carriers, which is one of the key conditions that influence the operating voltage and efficiency of OLEDs, is mainly due to energetic difference between the 


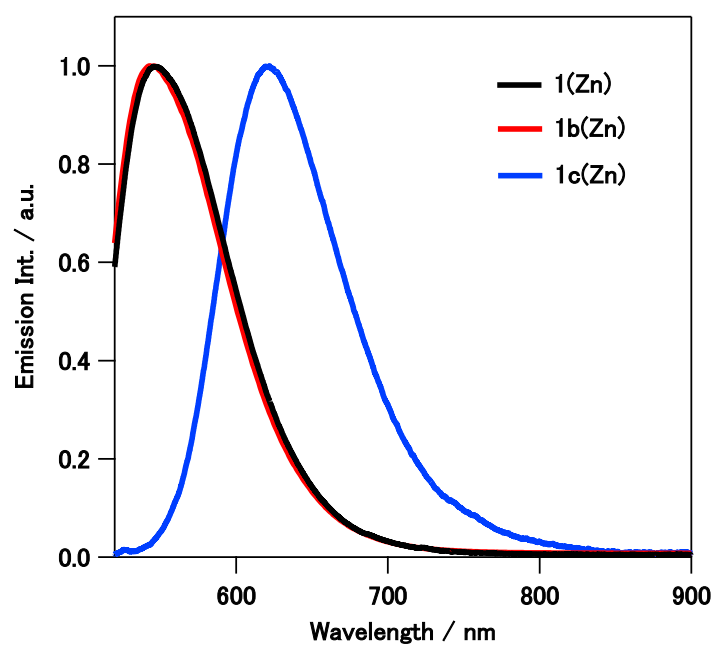

Figure 6. Emission spectra of $1(\mathrm{Zn}), 1 \mathrm{~b}(\mathrm{Zn})$ and $1 \mathrm{c}(\mathrm{Zn})$ in $\mathrm{CH}_{2} \mathrm{Cl}_{2}$, at $25{ }^{\circ} \mathrm{C}$ (for each compound, obtained by exciting at its absorption maximum wavelength).

Calculated results were listed in Table 3. Among these complexes, the complex $1 \mathrm{c}(\mathrm{Zn})$ possesses the smallest value of the HOMOLUMO gap. As clear from Figure 7, the frontier molecular orbitals of these zinc complexes are mainly dominated by atomic orbitals originating from the ligands in all cases and the contribution of $\mathrm{Zn}^{2+}$ cations is small because the $\mathrm{d}^{10} \mathrm{Zn}$ based levels are all filled and have lower energies (Table 4). These are similar to the salicylaldiminato zinc (II) complexes [8].
TD-DFT calculations were performed on the three complexes to calculate the nature and energy of the lowest energy transitions. The results, namely, the energy, wavelength, and oscillator strength of the more intense bands, were collected in Table 4. In terms of transitions, the oscillator strengths in the complexes are similar to those in the ligands. These calculations were performed taking into account the solvent $\left(\mathrm{CH}_{2} \mathrm{Cl}_{2}\right)$, but there were no significant differences from the behaviour in gas-phase.

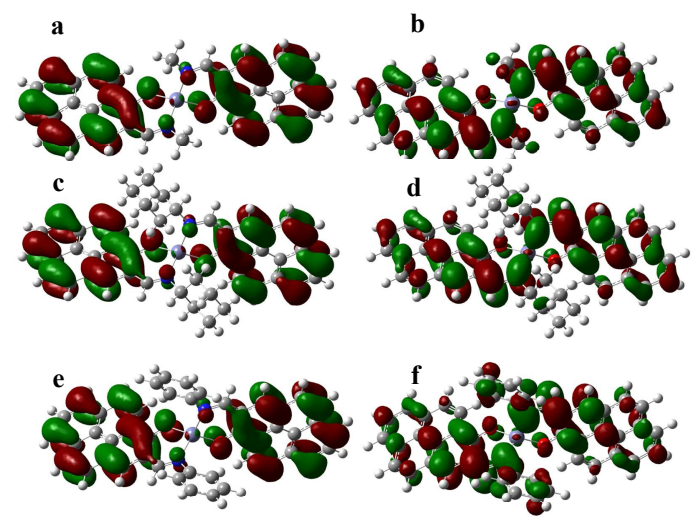

Figure 7: Plots of the (a) HOMO of 1(Zn), (b) LUMO of $1(\mathrm{Zn})$, (c) HOMO of $1 \mathrm{~b}(\mathrm{Zn})$, (d) LUMO of $1 b(\mathrm{Zn})$, (e) HOMO of $1 \mathrm{c}(\mathrm{Zn})$, and (f) LUMO of $1 \mathrm{c}(\mathrm{Zn})$ obtained from the RB3LYP/6-31g(d) level. All the MO surfaces correspond to an isocontour value $(0.02$ a.u.).

Table 2. Photophysical data of the zinc complexes in dichloromethane solution.

\begin{tabular}{|c|c|c|c|c|c|}
\hline Complexes & $\lambda_{\text {abs }}(\mathrm{nm})$ & $\begin{array}{c}\varepsilon_{\max } 10^{-4} \\
\left(\mathrm{M}^{-1} \mathrm{~cm}^{-1}\right)\end{array}$ & $\begin{array}{c}\Delta \lambda_{\text {abs }} \\
(\mathrm{nm})\end{array}$ & $\lambda_{\mathrm{em}}(\mathrm{nm})$ & $\Delta \lambda_{\mathrm{em}}(\mathrm{nm})$ \\
\hline $1(\mathrm{Zn})$ & 485 & 1.0 & - & 546 & - \\
\hline $1 \mathrm{~b}(\mathrm{Zn})$ & 485 & 1.3 & 0 & 546 & 0 \\
\hline $1 \mathrm{c}(\mathrm{Zn})$ & 508 & 1.2 & 23 & 622 & 76 \\
\hline
\end{tabular}

Table 3. Calculated data in gas-phase.

\begin{tabular}{|c|c|c|c|}
\hline Zinc complexes & HOMO $(\mathrm{eV})$ & LUMO $(\mathrm{eV})$ & $\mathrm{E}_{\mathrm{g}}(\mathrm{eV})$ \\
\hline $1(\mathrm{Zn})$ & -4.73 & -1.69 & 3.04 \\
\hline $1 \mathrm{~b}(\mathrm{Zn})$ & -4.73 & -1.69 & 3.04 \\
\hline $1 \mathrm{c}(\mathrm{Zn})$ & -4.79 & -1.96 & 2.83 \\
\hline
\end{tabular}


Table 4. Composition, Energy (eV), Calculated and Experimental Absorption Wavelengths (nm), and Oscillator Strength (OS) of the Electronic Transitions of the Zinc(II) Complexes $1(\mathrm{Zn}), 1 \mathrm{~b}(\mathrm{Zn})$, and $1 \mathrm{c}(\mathrm{Zn})$ in $\mathrm{CH}_{2} \mathrm{Cl}_{2}($ only transitions with: $\mathrm{OS}>0.01$ and Composition $>10 \%$ were considered, $\mathrm{H}=\mathrm{HOMO}, \mathrm{L}=\mathrm{LUMO}$ ).

\begin{tabular}{|c|c|c|c|c|c|}
\hline No. & Main Compositions & Energy $(\mathrm{eV})$ & $\begin{array}{l}\text { Wavelength } \\
(\mathrm{nm})\end{array}$ & $\lambda_{\exp }(\mathrm{nm})^{\mathrm{a}}$ & OS \\
\hline & & Ligand 1 & & & \\
\hline 1 & $\mathrm{H} \rightarrow \mathrm{L}(82 \%), \mathrm{H} \rightarrow \mathrm{L}+1(12 \%)$ & 3.07 & 404 & 430 & 0.12 \\
\hline 2 & $\mathrm{H} \rightarrow \mathrm{L}(11 \%), \mathrm{H} \rightarrow \mathrm{L}+1(79 \%)$ & 3.49 & 355 & & 0.28 \\
\hline 4 & $\begin{array}{l}\mathrm{H}-1 \rightarrow \mathrm{L}(48 \%), \mathrm{H}-1 \rightarrow \mathrm{L}+1(31 \%), \mathrm{H} \rightarrow \mathrm{L}+3 \\
(11 \%)\end{array}$ & 4.25 & 292 & & 0.14 \\
\hline 5 & $\mathrm{H}-1 \rightarrow \mathrm{L}(39 \%), \mathrm{H}-1 \rightarrow \mathrm{L}+1(46 \%)$ & 4.44 & 279 & & 1.26 \\
\hline \multirow[t]{2}{*}{6} & $\mathrm{H}-2 \rightarrow \mathrm{L}(76 \%)$ & 4.67 & 266 & & 0.07 \\
\hline & & Ligand $1 \mathrm{~b}$ & & & \\
\hline 1 & $\mathrm{H} \rightarrow \mathrm{L}(82 \%), \mathrm{H} \rightarrow \mathrm{L}+1(12 \%)$ & 3.07 & 404 & 430 & 0.13 \\
\hline 2 & $\mathrm{H} \rightarrow \mathrm{L}(11 \%), \mathrm{H} \rightarrow \mathrm{L}+1(79 \%)$ & 3.49 & 355 & & 0.28 \\
\hline 4 & $\begin{array}{l}\mathrm{H}-1 \rightarrow \mathrm{L}(52 \%), \mathrm{H}-1 \rightarrow \mathrm{L}+1(28 \%), \mathrm{H} \rightarrow \mathrm{L}+3 \\
(11 \%)\end{array}$ & 4.24 & 293 & & 0.17 \\
\hline 5 & $\mathrm{H}-1 \rightarrow \mathrm{L}(36 \%), \mathrm{H}-1 \rightarrow \mathrm{L}+1(49 \%)$ & 4.39 & 282 & & 1.44 \\
\hline \multirow[t]{2}{*}{7} & $\mathrm{H}-2 \rightarrow \mathrm{L}(75 \%), \mathrm{H}-2 \rightarrow \mathrm{L}+1(10 \%)$ & 4.67 & 266 & & 0.07 \\
\hline & & Ligand 1c & & & \\
\hline 1 & $H \rightarrow L(96 \%)$ & 2.79 & 445 & 448 & 0.14 \\
\hline 2 & $\mathrm{H}-1 \rightarrow \mathrm{L}(10 \%), \mathrm{H} \rightarrow \mathrm{L}+1(84 \%)$ & 3.47 & 357 & & 0.13 \\
\hline 3 & $\mathrm{H}-1 \rightarrow \mathrm{L}(84 \%)$ & 3.68 & 337 & & 1.42 \\
\hline 4 & $\mathrm{H}-1 \rightarrow \mathrm{L}+1(62 \%), \mathrm{H} \rightarrow \mathrm{L}+2(28 \%)$ & 4.02 & 308 & & 0.05 \\
\hline \multirow[t]{2}{*}{6} & $\mathrm{H}-6 \rightarrow \mathrm{L}(11 \%), \mathrm{H}-2 \rightarrow \mathrm{L}(63 \%)$ & 4.30 & 288 & & 0.42 \\
\hline & & \multicolumn{2}{|c|}{ Complex 1(Zn) } & & \\
\hline 1 & $\mathrm{H}-1 \rightarrow \mathrm{L}(48 \%), \mathrm{H} \rightarrow \mathrm{L}+1(48 \%)$ & 2.72 & 455 & 485 & 0.11 \\
\hline 2 & $\mathrm{H}-1 \rightarrow \mathrm{L}+1(29 \%), \mathrm{H} \rightarrow \mathrm{L}(67 \%)$ & 2.73 & 455 & & 0.19 \\
\hline 4 & $\mathrm{H}-1 \rightarrow \mathrm{L}+1(68 \%), \mathrm{H} \rightarrow \mathrm{L}(30 \%)$ & 2.82 & 439 & & 0.01 \\
\hline 5 & $H \rightarrow L+2(96 \%)$ & 3.33 & 372 & & 0.30 \\
\hline \multirow[t]{2}{*}{\begin{tabular}{|l|l}
7 \\
\end{tabular}} & $\mathrm{H}-1 \rightarrow \mathrm{L}+3(95 \%)$ & 3.38 & 367 & & 0.33 \\
\hline & & \multicolumn{2}{|c|}{ Complex 1b(Zn) } & & \\
\hline 1 & $\mathrm{H}-1 \rightarrow \mathrm{L}(77 \%), \mathrm{H} \rightarrow \mathrm{L}+1(20 \%)$ & 2.70 & 460 & 485 & 0.10 \\
\hline 2 & $\mathrm{H}-1 \rightarrow \mathrm{L}+1(19 \%), \mathrm{H} \rightarrow \mathrm{L}(77 \%)$ & 2.70 & 459 & & 0.19 \\
\hline 3 & $\begin{array}{l}\mathrm{H}-1 \rightarrow \mathrm{L}+1(36 \%), \mathrm{H} \rightarrow \mathrm{L}(12 \%), \\
\mathrm{H} \rightarrow \mathrm{L}+1(42 \%)\end{array}$ & 2.82 & 440 & & 0.02 \\
\hline 4 & $\begin{array}{l}H-1 \rightarrow L(12 \%), H-1 \rightarrow L+1(43 \%), \\
H \rightarrow L+1(35 \%)\end{array}$ & 2.82 & 440 & & 0.02 \\
\hline \multirow[t]{2}{*}{5} & $H \rightarrow L+2(96 \%)$ & 3.34 & 372 & & 0.30 \\
\hline & & \multicolumn{2}{|c|}{ Complex 1c(Zn) } & & \\
\hline 1 & $\mathrm{H}-1 \rightarrow \mathrm{L}+1(13 \%), \mathrm{H} \rightarrow \mathrm{L}(85 \%)$ & 2.49 & 498 & 508 & 0.16 \\
\hline 2 & $\mathrm{H}-1 \rightarrow \mathrm{L}(71 \%), \mathrm{H} \rightarrow \mathrm{L}+1(28 \%)$ & 2.50 & 497 & & 0.15 \\
\hline 3 & $\mathrm{H}-1 \rightarrow \mathrm{L}(28 \%), \mathrm{H} \rightarrow \mathrm{L}+1(71 \%)$ & 2.58 & 480 & & 0.01 \\
\hline 4 & $\mathrm{H}-1 \rightarrow \mathrm{L}+1(85 \%), \mathrm{H} \rightarrow \mathrm{L}(14 \%)$ & 2.59 & 478 & & 0.04 \\
\hline 5 & $H \rightarrow L+2(95 \%)$ & 3.32 & 374 & & 0.24 \\
\hline
\end{tabular}




\section{Conclusions}

A series of pyrene-based bis(salicylaldiminato)-type zinc complexes have been synthesized and characterized successfully in good to excellent yields. Our research results indicate that the chelating pyrene-based bidentate salicylaldiminato-type conjugated ligands are well suitable for synthesizing four-coordinate zinc complexes by the reaction of commercial zinc acetate with the corresponding ligands. These complexes produce bright fluorescence in solution, and the emission color in solution can be tuned by the change of the substituents on imine group of the ligands. The four-coordinate zinc complexes are a new class of luminescent material with potential applications in opto-electronic devices.

\section{Appendix A. Supplementary material}

CCDC 1973750 contains the supplementary crystallographic data for 2019/12/22. These data can be obtained free of charge via http://www.ccdc.cam.ac.uk/conts/retrieving.htm 1, or from the Cambridge Crystallographic Data Centre, 12 Union Road, Cambridge CB2 1EZ, UK; fax: (+44) 1223-336-033; or e-mail: deposit@ccdc.cam.ac.uk.

$\dagger$ Electronic supplementary information $(E S I)$ is available: i.e., ESI-\#1: $\mathrm{x}$-ray structure report, and CIF-file of $\mathbf{1 b}(\mathbf{Z n})$, CCDC 1973750. For ESIs and crystallographic data in CIF or another electronic format see DOI: XXXXXXXXXXX

\section{Acknowledgements}

This work was supported in part by the Priority Research Program sponsored by the Asian Human Resources Fund from Tokyo Metropolitan Government (TMG), a research grant funded by Vietnam Ministry of Education and Training (Grant No. B2021-BKA-19), and a research grant funded by Vietnam Electricity Power Generation Corporation 1 (Grant No. 84/HĐ-KHCN-EVNGENCO1-BKHN). L.X.D. appreciates Tokyo Metropolitan University (TMU) for a pre-doctoral fellowship. We appreciate the scientific and supervision support of Ken-ichi Sugiura and Ken-ichi Yamashita (TMU). Also, the authors thank Mr. Toshihiko
Sakurai (TMU) for elemental analyses.

\section{References}

[1] F. Dumur, Zinc complexes in OLEDs: An Overview, Synthetic Met., Vol. 195, 2014, pp. 241-251. https://doi.org/10.1016/j.synthmet.2014.06.018.

[2] W. A. Zoubi, Biological Activities of Schiff Bases and Their Complexes: A Review of Recent Works, International Journal of Organic Chemistry, Vol. 3, 2013, pp. 73-95. https://doi.org/-10.4236/ijoc.2013.33A008.

[3] S. D. Bella, I. P. Oliveri, A. Colombo, C. Dragonetti, S. Righetto, D. Roberto, An Unprecedented Switching of the Second-Order Nonlinear Optical Response in Aggregate Bis(Salicylaldiminato)Zinc(Ii) Schiff-Base Complexes, Dalton Trans., Vol. 41, 2012, pp. 7013-7016. https://doi.org/10.1039/C2DT30702B.

[4] C. Evans, D. Luneau, New Schiff Base Zinc(Ii) Complexes Exhibiting Second Harmonic Generation, J. Chem. Soc., Dalton Trans., 2002, pp. 83-86. https://doi.org/10.1039/B104360A.

[5] C. S. B. Gomes, P. T. Gomes, M. T. Duarte, R. E. D. Paolo, A. L. Macanita, M. J. Calhorda, Synthesis, Structure, and Photophysical Characterization of Blue-Green Luminescent Zinc Complexes Containing 2-Iminophenanthropyrrolyl Ligands, Inorg. Chem., Vol. 48, 2009, pp. 11176-11186. https://doi.org/-10.1021/ic9015-19s.

[6] L. Shi, R. Q. Fang, J. Y. Xue, Z. P. Xiao, S.-H. Tan, H. L. Zhu, Synthesis, Characterization, and Antibacterial and Cytotoxic Study of Metal Complexes with Schiff Base Ligands, Australian Journal of Chemistry, Vol. 61, No. 4, 2008, pp. 288-296. https://doi.org/10.1071/-CH07408.

[7] L. Li, C. S. B. Gomes, P. T. Gomes, M. T. Duarte, Z. Fan, New Tetradentate N,N,N,N-Chelating ADiimine Ligands and Their Corresponding Zinc and Nickel Complexes: Synthesis, Characterisation and Testing as Olefin Polymerisation Catalysts, Dalton Trans., Vol. 40, 2001, pp. 3365-3380. https://doi.org/10.1039/C0DT01308K.

[8] L. Chen, J. Qiao, J. Xie, L. Duan, D. Zhang, L. Wang, Y. Qiu, Substituted azomethine-zinc complexes: Thermal Stability, Photophysical, Electrochemical and Electron Transport Properties, Inorganica Chimica Acta, Vol. 362, 2009, pp. 2327-2333. https://doi.org/10.1016/j.ica.2008.10.016.

[9] M. G. Kaplunov, I. K. Yakushchenko, S. S. Krasnikova, S. N. Shamaev, A. P. Pivovarov, O. N. Efimov, New Electroluminescent Materials Based on Chelate Zinc Complexes, Russian 
Chemical Bulletin, Vol. 53, 2004, pp. 2148-2151. https://doi.org/10.1007/s11172-005-0088-8.

[10] M. E. Germain, T. R. Vargo, P. G. Khalifah, M. J. Knapp, Fluorescent Detection of Nitroaromatics and 2,3-Dimethyl- 2,3-dinitrobutane (DMNB) by a Zinc Complex: (salophen)Zn, Inorg. Chem., Vol. 46, 2007, pp. 4422-4429. https://doi.org/10.1021/ic062012c.

[11] M. A. Torzilli, S. Colquhoun, D. Doucet, R. H. Beer, The Interconversion of Dichlorobis(N-npropylsalicylaldimine)zinc(II) and Bis(N-npropylsalicylaldiminato)zinc(II) Polyhedron, Vol. 21, 2002, pp. 697-704. https://doi.org/10.1016/S0277-5387(02)00839-2.

[12] M. Montazerozohori, S. M. Jahromi, A. Masoudiasl, P. McArdle, Molecular and biomolecular spectroscopy, Spectrochimica Acta. Part A, Vol. 138, 2015, pp. 517-528. https://doi.org/10.1016/-j.saa.2014.11.055.

[13] I. P. Oliveri, S. Failla, A. Colombo, C. Dragonetti, S. Righetto, S. D. Bella, Synthesis, Characterization, Optical Absorption/ Fluorescence Spectroscopy, and Second-Order Nonlinear Optical Properties of Aggregate Molecular Architectures of Unsymmetrical SchiffBase Zinc(Ii) Complexes Dalton Trans., Vol. 43, 2014, pp. 2168-2175. https://doi.org/10.1039/C3DT53072H.

[14] I. P. Oliveri, S. Failla, G. Malandrino, S. D. Bella, New Molecular Architectures by Aggregation of Tailored Zinc(Ii) Schiff-Base Complexes, New. J. Chem., Vol. 35, 2011, pp. 2826-2831. https://doi.org/10.1039/C1NJ20618D.

[15] I. P. Oliveri, S. Failla, G. Malandrino, S. D. Bella, Controlling the Molecular Self-Assembly into Nanofibers of Amphiphilic Zinc(II) Salophen Complexes, J. Phys. Chem. C, Vol. 117, 2013, pp. 15335-15341. https://doi.org/10.1021/jp4038182.

[16] I. P. Oliveri, G. Maccarrone, S. D. Bella, A Lewis Basicity Scale in Dichloromethane for Amines and Common Nonprotogenic Solvents Using a Zinc(II) Schiff-Base Complex as Reference Lewis Acid, J. Org. Chem., Vol. 76, 2011, pp. 8879-8884. https://doi.org/-10.1021/jo2016218.

[17] I. P. Oliveri, G. Malandrino, S. D. Bella, SelfAssembled Nanostructures of Amphiphilic Zinc(Ii) Salophen Complexes: Role of the Solvent on Their Structure and Morphology, Dalton Trans., Vol. 43, 2014, pp. 10208-10214. https://doi.org/10.1039/C4DT00973H.

[18] I. P. Oliveri, G. Malandrino, S. D. Bella, Supramolecular Aggregation/Deaggregation in Amphiphilic Dipolar Schiff-Base Zinc(II)
Complexes, Inorg. Chem., Vol. 53, 2014, pp. 9771-9777. https://doi.org/-10.1021/ic5013632.

[19] P. Wang, Z. Hong, Z. Xie, S. Tong, O. Wong, C.-S. Lee, N. Wong, L. Hung, S. Lee, A BisSalicylaldiminato Schiff Base and Its Zinc Complex as New Highly Fluorescent Red Dopants for High Performance Organic Electroluminescence Devices, Chem. Commun., 2003, pp.1664-1665. https://doi.org/10.1039/B303591C.

[20] T. Yu, W. Su, W. Li, Z. Hong, R. Hua, B. Li, A Schiff Base Zinc Complex and its Electroluminescent Properties, Thin Solid Films, Vol. 515, 2007, 4080. https://doi.org/10.1016/j.tsf.2006.11.001.

[21] L. X. Dien, K. Yamashita, M. S. Asano, K. Sugiura, Syntheses of A Pyrene-Based П-Expanded Ligand and the Corresponding Platinum(II) Complex, Bis[2-[(Octylimino)Methyl]-1-Pyrenolato-N,O] Platinum(II), Inorg. Chim. Acta, Vol. 432, 2015, pp. 103-108. https://doi.org/10.1016/j.ica.2015.03.038.

[22] T. Ohno, S. Kato, A. Takeuchi, S. Yamada, Excited States of N-Salicylidenealkylamines Chelating to Zinc(II), Bull. Chem. Soc. Jpn., Vol 50, 1977, pp. 6-9. https://doi.org/-10.1246/bcsj.50.6.

[23] G. E Batley, D. P Graddon, Studies in the Stereochemistry Of Zinc(II). V. Zinc Complexes With N-Alkylsalicylaldimines, Australian Journal of Chemistry, Vol. 20, 1967, pp. 877-883. https://doi.org/-10.1071/CH9670877.

[24] H. N. Hou, Acta Cryst. Bis[2(cyclo-hexyl-imino-methyl)-phenolato]zinc(II), E61, 2005, pp. m1197-m1198. https://doi.org/10.1107/S1600536805015990.

[25] Z. L. You, Bis[2-(cyclo-hexyl-imino-meth-yl)-4nitro-phenolato]zinc(II), Acta Cryst., E61, 2005, pp. m2495-m2496. https://doi.org/10.1107/S1600536805035531.

[26] Z. X. Li, X. L. Zhang, Bis[4-chloro-2(cyclo-hexyl-imino-meth-yl)phenolato]zinc(II), Acta Cryst., E61, 2005, pp. m1755-m1756. https://doi.org/10.1107/-S1600536805025250.

[27] P. Demerseman, J. Einhorn, R. Royer, J. F. Gourvest, Synthèse D'analogues Furanniques du Benzo[a]pyrene, J. Heterocycl. Chem., Vol. 22, 1985, pp. 39-43. https://doi.org/10.1002/jhet.5570220110.

[28] L. X. Dien, K. Yamashita, K. Sugiura, Metal Complexes of $\pi$-expanded Ligands (2): Synthesis and Characterizations of bis[2[(octylimino)methyl]-1-pyrenolato-N,O] palladium(II) and the Stabilized Vacant dx2 - y2 
orbital, Polyhedron, Vol. 102, 2015, pp. 69-74. https://doi.org/10.1016/-j.poly.2015.07.043.

[29] L. X. Dien, N. X. Truong, N. D. Quan, K. Yamashita, K. Sugiura, Synthesizing and Studying the Structure of Ni(II) Complexes Containing 2-alkyliminomethyl Pyrene Ligands, VNU Journal of Science, Vol. 34, No. 4, 2018 , pp. 16-20. https://doi.org/-10.25073/2588-1140/vnunst.4809.

[30] L. X. Dien, N. K. Nga, N. X. Truong, K. Yamashita,

K. Sugiura, Metal Complexes of $\pi$-Expanded Ligands (4): Synthesis and Characterizations of Copper(II) Complexes with a Schiff Base Ligand Derived from Pyrene, VNU Journal of Science, Vol. 35, No. 2, 2019, pp. 98-105.

https://doi.org/10.25073/25881140/-vnunst.4898. 